\title{
Compressibility of kaolinite treated with fly ash from fluidized bed combustion
}

\author{
Karolina Knapik ${ }^{1,3}$, Joanna Bzówka², Giacomo Russo ${ }^{3}$ \\ 1,2 Department of Geotechnics and Roads, Faculty of Civil Engineering, The Silesian University of \\ Technology,e-mail: ${ }^{1}$ karolina.knapik@polsl.pl; ${ }^{2}$ joanna.bzowka@polsl.pl \\ ${ }^{3}$ Department of Civil and Mechanical Engineering, University of Cassino and Southern Lazio, \\ e-mail: giarusso@unicas.it
}

\begin{abstract}
Waste products such as fly ash can be an economically advantageous alternative for lime and cement in ground improvement techniques. Current state of knowledge indicates the possibility of using this material successfully in various engineering projects. However, the chemical composition of fly ash is related to the type of coal and combustion technology used in power plant. This fact indicates need for further studies aiming determination the effect of fly ash addition on soil properties. Rate of soil improvement considered in macro level includes designation of treated soil mechanical properties, inter alia compressibility characteristics. Presented results of laboratory tests are a part of a larger experimental work aiming to determine the suitability of fly ash from fluidized bed combustion for the purpose of soil strengthen with the use of selected ground improvement.
\end{abstract} strain.

Keywords: kaolinite, fly ash, fluidized bed combustion, porosity index, volume

\section{Introduction}

Fly ash from fluidized bed combustion is a waste material produced in power plants. Given the nature of combustion technology fluidal fly ash can contain relatively high amount of calcium compounds. Part of calcium is present as a free and highly reactive $\mathrm{CaO}$. Due to the fact that this material contains also $\mathrm{SiO}_{2}$ (from 5 to $50 \%$ [1]) and $\mathrm{Al}_{2} \mathrm{O}_{3}$ (from 4 to $25 \%$ [1]) it can show pozzolanic - hydraulic activity and can be considered as a material used in ground improvement techniques.

Under certain conditions lime addition to the fine grained soil results in cation exchange and pozzolanic reaction. These mechanisms, referred to as modification and stabilization of treated soils respectively ([2], [9]) develop simultaneously but with different time scale.

Cation exchange involves replacing ions from clay minerals with calcium ions from lime. This may occur at very short time and results in flocculation of soil particles during fabric formation. Important factors affecting kaolinite fabric formation are described in literature [7], [8], [10]. These include the $\mathrm{pH}$ and particle - particle interactions. Particles can be charged negatively or positively due to the $\mathrm{pH}$ value. Surface charge modification occurs through the process of protonation, deprotonation and cation complexation. In kaolinite at low $\mathrm{pH}$ of environment aluminum dissociates preferentially and at high value of the $\mathrm{pH}$ this phenomena refers to silica [8].

Upon contact with water free $\mathrm{CaO}$ from fly ash or lime reacts in short term. This time depends on amount of available free $\mathrm{CaO}$ and ambient temperature [1]. Usually hydratation 
takes place within 2 to 7 hours [4]. Pozzolanic reaction between $\mathrm{Ca}(\mathrm{OH})_{2}$ and pozzolanic compounds occurs in longer term provides stable products such as hydrated calcium silicates and aluminates [2], [3], [5]. Important factor is relatively high $\mathrm{pH}$ value, which determines the possibility of dissolution of silica and alumina and their connection with calcium ions. Last research results carried out by the authors confirmed the variation of the $\mathrm{pH}$ value in time and increasing $\mathrm{pH}$ value with increasing fly ash or lime quantity [6].

The aim of this experimental work is to demonstrate compressibility behavior of fine grained soil treated with fly ash from fluidized bed combustion without (or with) lime addition. Mixtures were prepared in various composition in order to highlight the impact of individual components on compressibility tested at different curing time.

\section{Experimental procedures}

In experimental procedure mentioned below following materials were used:

- fine grained soil - Speswhite kaolinite (specific gravity $2,60 \mathrm{~g} / \mathrm{cm}^{3}$ ),

- fluidal fly ash (specific gravity $2,77 \mathrm{~g} / \mathrm{cm}^{3}$ ),

- quicklime.

In order to detect differences in compressibility behavior between natural soil and soil treated with fly ash or with fly ash and lime, oedometer tests were performed. Air dried components were mixed by hand with distilled water and stored in closed containers in order to prevent water loss. Proportions of materials in the mixtures are shown in Table 1.

Table 1. Proportions of components in mixtures used for oedometer tests

\begin{tabular}{ccccc}
\hline Mixture & Soil $[\mathrm{g}]$ & Fly ash $[\mathrm{g}]$ & Lime $[\mathrm{g}]$ & Water $[\mathrm{g}]$ \\
\hline Kaolinite & 100 & - & - & 100 \\
\hline FA $10 \%$ & 100 & 10 & - & 110 \\
\hline FA $10 \%+1 \%$ lime & 100 & 10 & 1 & 111 \\
\hline FA $20 \%$ & 100 & 20 & - & 120 \\
\hline FA $30 \%$ & 100 & 30 & - & 130 \\
\hline FA $40 \%$ & 100 & 40 & - & 140 \\
\hline
\end{tabular}

After required time (after 21 hours for mixtures tested at 0 day of curing time and after 7 days) material was put in oedometer ring.

Oedometer test was performed with cell filled with water. In order to monitor the consolidation process settlements were read in $1 \mathrm{sec}$. intervals. Sample was loaded with 12 steps (up to the load $1220 \mathrm{kPa}$ ) and unloaded with 6 steps. At the end of the test water content was measured.

\section{Results}

Figures 1, 2, 3 and 4 present the results obtained from oedometer tests carried out for natural soil and treated soil at 0 day of curing time and after 7 days of curing time. Data are plotted in terms of void ratio $e$ and vertical stress $\sigma^{\prime}{ }_{v}$. It can be noted that addition of fly ash leads to increase void ratio $e$ both at 0 day and after 7 days of curing.

The behaviour upon loading of the treated soil, for high percentage of fly ash and longer curing time, shows a well defined transition between the reversible and the not reversible behaviour, allowing the identification of the yield stress. Significant role of curing time can be observed for mixtures of soil and fly ash in amount of $40 \%$ (Figure 4 ). 


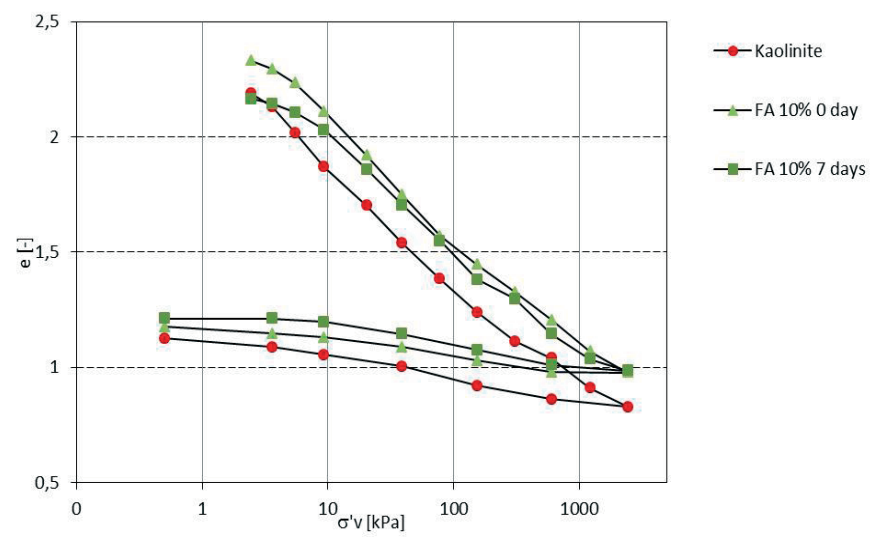

Fig. 1. Compressibility curves from oedometer tests obtained for natural soil and mixture FA $10 \%-$ relations between vertical stress $\sigma_{v}^{\prime}$ and void ratio $e$

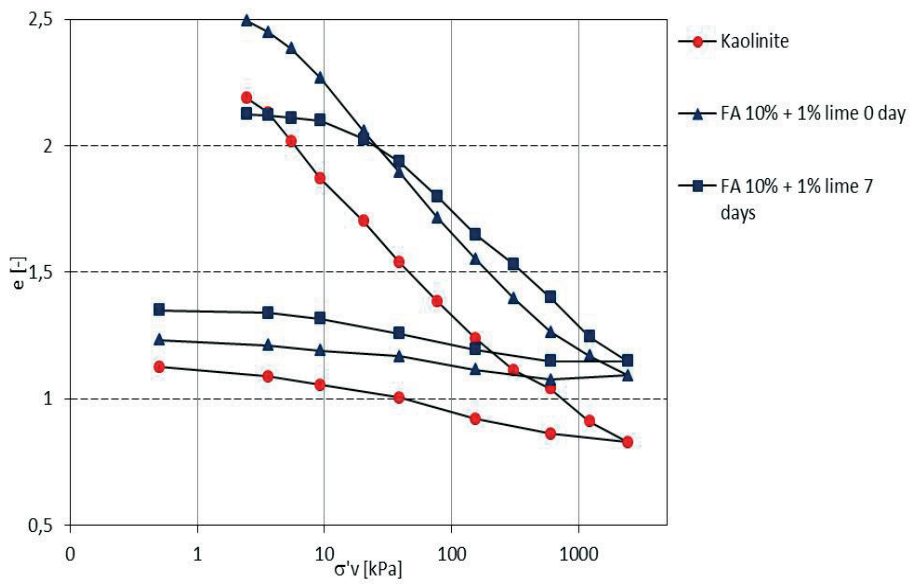

Fig. 2. Compressibility curves from oedometer tests obtained for natural soil and mixture FA $10 \%+1 \%$ lime - relations between vertical stress $\sigma^{\prime}{ }_{v}$ and void ratio $e$

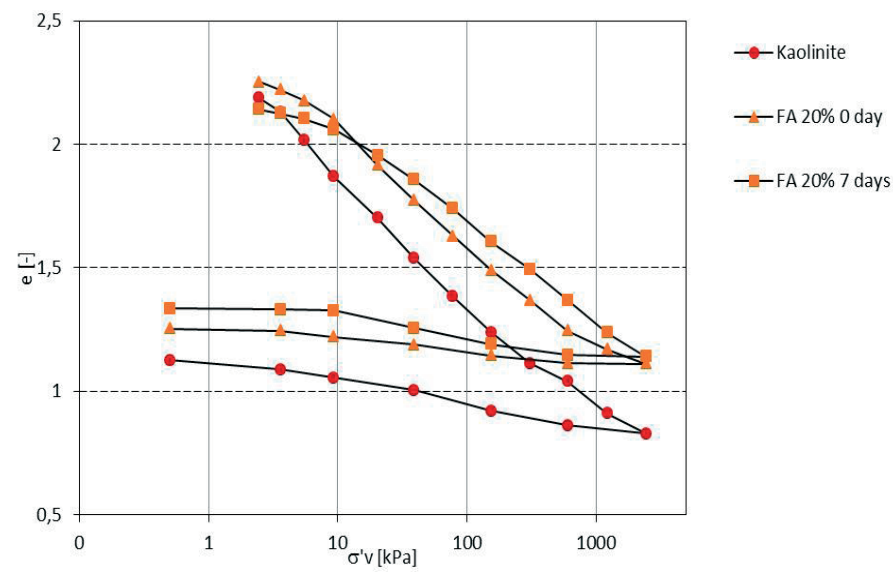

Fig. 3 Compressibility curves from oedometer tests obtained for natural soil and mixture FA $20 \%-$ relations between vertical stress $\sigma^{\prime}{ }_{v}$ and void ratio $e$ 


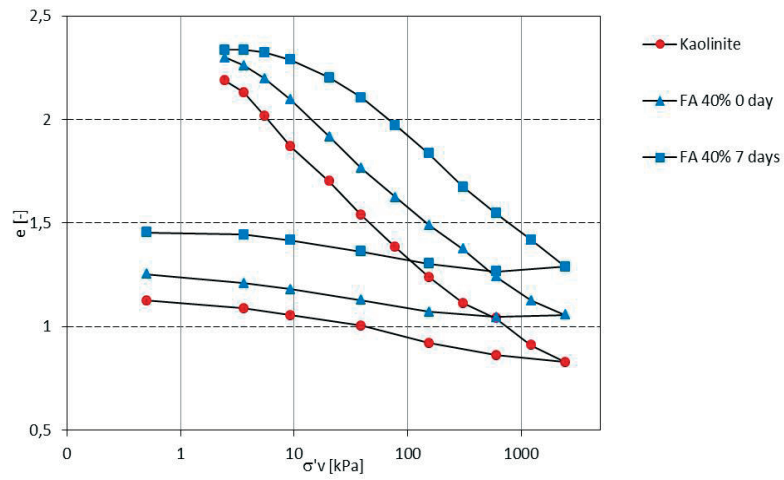

Fig. 4. Compressibility curves from oedometer tests obtained for natural soil and mixture FA $40 \%-$ relations between vertical stress $\sigma_{v}^{\prime}$ and void ratio

Larger void ratio changes can be noted for vertical stress higher than 9,3 kPa. Table 2 . presents compession index $C c$ obtained for normal compression line (NCL). There is no signifiant impact of fly ash, lime addition and curing time in comparison with natural soil. However, swelling index obtained for unloading curves tends to decrease with increasing fly ash content. That data reveals higher stiffness of treated material.

Table 2. Comparison of compression index $C c$ and swelling index $C s$

\begin{tabular}{ccccc}
\hline \multirow{2}{*}{ Name } & \multicolumn{2}{c}{ Compression index $C c[-]$} & \multicolumn{2}{c}{ Swelling index $C s[-]$} \\
\cline { 2 - 5 } & 0 day & 7 days & 0 day & 7 days \\
\hline Kaolinite & \multicolumn{3}{c}{0,42} & \multicolumn{2}{c}{0,08} \\
\hline FA $10 \%$ & 0,45 & 0,42 & 0,05 & 0,06 \\
\hline FA 10\% + 1\% lime & 0,46 & 0,42 & 0,04 & 0,05 \\
\hline FA 20\% & 0,39 & 0,39 & 0,04 & 0,05 \\
\hline FA 40\% & 0,41 & 0,44 & 0,05 & 0,05 \\
\hline
\end{tabular}

The same data are plotted in the Figures 5 and 6 in terms of volume strain $\varepsilon_{v}$ and vertical stress $\sigma_{v}^{\prime}$ in order to compare loading paths without influence of different initial void ratio for each mixture. Compressibility curves obtained for soil treated with $10 \%$ of fly ash and $1 \%$ of lime, $20 \%$ of fly ash and $40 \%$ of fly ash after 7 days of curing time (Figure 6 ) reveal increased stiffness. For mixture of soil treated with $10 \%$ of fly ash compressibility curve was obtained as the intermediate result.

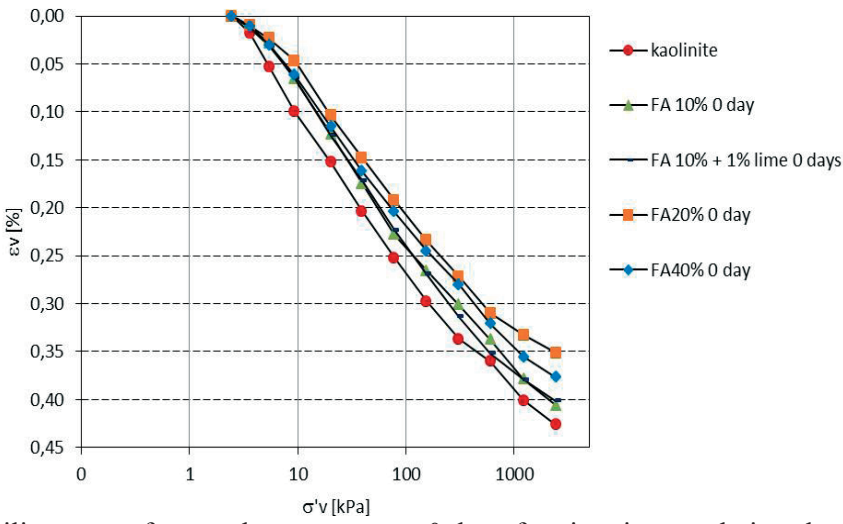

Fig. 5. Compressibility curves from oedometer tests at 0 day of curing time - relations between vertical stress $\sigma^{\prime}{ }_{v}$ and volume strain $\varepsilon_{v}$ 


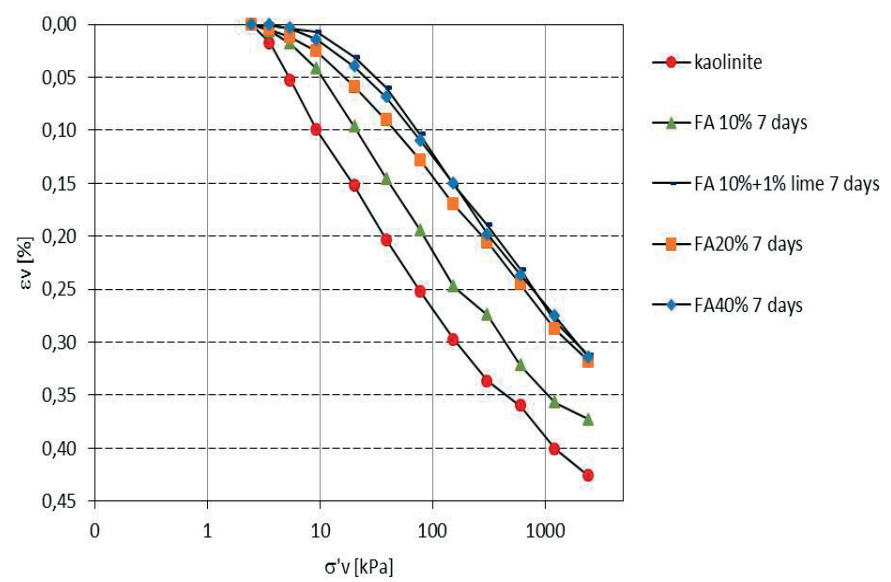

Fig. 6. Compressibility curves from oedometer tests after 7 days of curing time - relations between vertical stress $\sigma_{v}^{\prime}$ and volume strain $\varepsilon_{v}$

\section{Conclusions}

In the paper some results of an ongoing experimental research on the soil treatment by addition of fly ashes and lime have been discussed, with reference to the mechanical behaviour of treated samples during one dimensional compression tests (oedometer tests). The samples were prepared at high water content (above the liquid limit of the treated soils) by mixing kaolin with various amount of fly ash and lime, and cured for different time intervals.

The results evidenced the improvement of the mechanical behavior of the treated soil in the short term, with a decrease of compressibility which is relevant for high percentages of fly ash and tends to increase with longer curing times. The addition of lime enhances this trend. The behaviour upon loading of the treated soil, for high percentage of fly ash and longer curing time, shows a well defined transition between the reversible and the not reversible behaviour, allowing the identification of the yield stress. The increase of yield stress over the time is probably due to the effects of bonding compounds forming at the microstructure level, as a result of the pozzolanic activity favoured by the highly alkaline environment induced by calcium cations. Further investigation are currently running to investigate the effects of fly ash and lime on the evolution of the mechanical behaviour of the kaolin, with reference to different scales of observation.

Karolina Knapik is a scholar of the project "DoktoRIS - Scholarship program for innovative Silesia" co-financed by the European Union - European Social Fund.

\section{References}

1 Bulewicz E. M. Specyfika składu i właściwości popiołów z procesów fluidalnego spalania węgli. Popioły z energetyki. Zakopane, 21-24 października 2009, 9-19.

2 Cecconi M., Pane V., Marmottini, Russo G., Croce P., dal Vecchio S. Lime stabilization of pyroclastic soils, in: Soil improvement techniques based on the use of lime and cement. Research Project Funded by C.N.R. Università degli Studi di Cassino e del Lazio Meridionale, Università degli Studi di Perugia, Università Politecnica delle Marche. Hevelius Edizioni \& Betelgeuse s.r.l. da Aesse Stampa - Benevrnto, 2013, 164-168. 
3 Eades J.L. \& Grim R.E. A quick test to determine lime requirements for lime stabilization. Highway Research Records, No. 139 (1966), 61-72.

4 Giergiczny Z. The role of calcium and siliceous fly ash in the formulation of modern binders and cementous materials' properties (in Polish). Wydawnictwo Politechniki Krakowskiej, Kraków, 2006.

5 Glenn G.R., Handy R.L. Lime clay mineral reaction products. Highway Research Record, No 29 (1963), 70-82.

6 Knapik K., Bzówka J., Russo G. The pH value of kaolinite treated with fluidal fly ash and lime. Reinforcement, sealing and anchoring of rock massif and building structures 2014, Ostrava 27 28 February, 87-93.

7 Mitchell J. K., Soga K. Fundamentals of Soil Behavior. Third Edition, John Wiley \& Sons, INC., Hoboken, New Jersey, 2005.

8 Palomino A. M., Santamarina J. C. Fabric map kaolinite: effects of $\mathrm{pH}$ and ionic concentration on behavior. Clays and Clay Minerals, Vol. 53, No. 3 (2005), 209-222.

9 Rogers C.D.F., Glendinning S. Modification of Clay Soils using Lime, in: Lime Stabilisation. (Rogers C.D.F., Glendinning S., Dixon N. (eds.)). Thomas Telford, London 1996, p. 99-126.

10 Van Olphen H. An introduction to Clay Colloid Chemistry. Interscience publishers a division of John Wiley \& Sons, New York, 1977.

\title{
Ściśliwość mieszaniny kaolinu i popiołu lotnego z fluidalnego spalania węgla
}

\author{
Karolina Knapik ${ }^{1,3}$, Joanna Bzówka², Giacomo Russo ${ }^{3}$ \\ ${ }^{1,2}$ Katedra Geotechniki i Dróg, Wydziat Budownictwa, Politechnika Ślaska, \\ e-mail: ${ }^{1}$ karolina.knapik@polsl.pl; ${ }^{2}$ joanna.bzowka@polsl.pl \\ ${ }^{3}$ Dipartamento di Ingegneria Civile e Meccanica, Università di Cassino e del Lazio Meridionale, \\ e-mail:giarusso@unicas.it
}

Streszczenie: Odpady takie jak popioły lotne mogą stanowić korzystną pod względem ekonomicznym alternatywę dla wapna i cementu $\mathrm{w}$ technikach wzmacniania podłoża gruntowego. Obecny stan wiedzy wskazuje na możliwość wykorzystywania tego materiału z powodzeniem w różnych przedsięwzięciach inżynierskich. Jednakże skład chemiczny popiołów lotnych jest związany $\mathrm{z}$ rodzajem węgla oraz technologią spalania przyjętą w elektrowni. Ten fakt wskazuje na konieczność poszerzania bazy doświadczalnej, mającej na celu określenie wpływu dodatku popiołu lotnego na właściwości gruntu. Stopień wzmocnienia gruntu rozpatrywany $\mathrm{w}$ skali makro obejmuje oznaczenie mechanicznych właściwości gruntu wzmacnianego, w tym charakterystyki ściśliwości. Przedstawione wyniki badań laboratoryjnych stanowią część projektu badawczego, mającego na celu określenie przydatności popiołów lotnych pochodzących z fluidalnego spalania węgla do celów wzmacniania gruntu przy wykorzystaniu wybranych technik wzmacniania podłoża gruntowego.

Słowa kluczowe: kaolin, popiół lotny, fluidalne spalanie węgla, fly ash, fluidized bed combustion, wskaźnik porowatości, odkształcenie objętościowe 